\title{
РОЗВИТОК САМООРГАНІЗАЦІЇ СТУДЕНТІВ ПРИ ВИВЧЕННІ ХІМІЧНИХ ДИСЦИПЛІН
}

Описується як за допомогою рефлексії може відбуватися проиес самоорганізації у студентів, який є важливий для подальшого становлення та для самовизначення людини у світі. Стати більш конкурентно-спроможним на ринку прачі і у світі. Детально наведені основні аспекти розподілу власного часу в період навчальної діяльності студента. Саме правильний розподіл вільного часу допомагає студентові навчатися самоорганізовувати себе. Розглядається детально основні компоненти за допомогою, яких можна розвинути та сформувати вміння до самоорганізації. головною задачею у формуванні самоорганізаиії вмінь студентів повинно стати розвиток рефлексії у студентів. Необхідно студента навчити ставати у рефлексивну позицію, тобто розуміти власну дію. В праці Богіна В.Г. [2] для навчально пізнавальної діяльності головне, щуоб відбувалися рефлексивні переноси з одної площини в іншу. Для того, щчоб навчити студента самоосвіті та самоорганізації потрібно навчити його рефлексії. Описується головна задача у формуванні самоорганізаційних вмінь, які відбуваються лише під дією рефлексійних дій, а це і є головне при вивченні хімічних дисциилін розуміти власні діï.

Детально розглядається «ситуачія розриву», яка викликає рефлексійні дії у студентів під час самостійного вирішування проблеми. Ця ситуачія надає змогу закріпити отриманні нові знання, та одночасно нагадати вміння, які вже має студент і спроектувати нові знання в іншу площу знань. Наводиться група хімічних компетенцій, яка притаманна для студентів фармацевтичних факультетів. Саме иі компетениії є фундаментальними для вивчення професійно-орієнтованих дисичплін для студентів фармачевтичних вищих навчальних закладів.

Схарактеризовані критерії рефлексивної здатності, які тісно пов 'язані зі самостійною працею студента у вищих навчальних закладах. Виокремлюються два основних аспекту, на яких базується процес самостійної діяльності студента під час навчального проиесу.

Зазначено, щзо для того, аби розвинути компетенцій потрібно, щэоб студент вмів самоорганізовуватися. Саме у формуванні хімічних компетениій самоорганізаційна діяльність є педагогічною умовою успішності. Таким чином, щоб найкраще сформувати та розвити хімічні компетенції в процесі самоосвітньої діяльності студента потрібно підтримувати наступні умови на кожному практичному занятті:

Ключові слова: самоорганізачія, самовизначення, «ситуація розриву», самостійна діяльність, хімічні компетенції.

Успішність особистісного самовизначення залежить від того, наскільки особистість добре інтегрована, від ії креативності, базової культури, від ступеня освоєння норм поведінки і спілкування, від уміння входити в складний сучасний світ, адаптуватися у великому потоці інформації. У зв'язку з цим виникає необхідність у стимулюванні активності самої особистості, ії прагнення до саморозвитку і самовизначення через самопізнання, здатності до адекватних відповіді викликам сучасного складного та складно координованого світу. Внаслідок цього особистість повинна вміти самоорганізовуватися.

Для того, щоб викликати процес самоорганізації, потрібно студентам мати вміння до рефлексії. Ми вважаємо, що найкраще для розвитку самоорганізації студентові потрібно організувати власний час в період навчання. Можна визначити основні аспекти розподілу власного часу в період навчання:

- змістове планування - потрібно виділити чітко ціль, під ціль, головні задачі власної діяльності з точки зору їх змістового значення саме для студента, обов'язково привести їх в певній послідовності за ступеням важності;

- постійний контроль при вирішенні задач, витрат часу при виконанні явних задач та досягнення цілі;

- ймовірне прогнозування. Цей момент дозволяє запланувати свою роботу при навчанні на місяць або на рік;

- Виконавчий контроль порядку, швидкості виконання.

Як показав літературний пошук за автором М.М. Курневим [1] в систему формування вмінь самоорганізації студентів входять наступні компоненти:

- Забезпечення студента інформаційною базою о сутті самоорганізації;

- Діагностика вихідних вмінь самоорганізації;

- Виокремлювання пріоритетних цілей, а саме формування вмінь самоорганізації. Досягнення високого рівня в їх формуванні;

- (Само)прогнозування та (само)проектування;

- Змістовно-операційне забезпечення процесом самоорганізації, обов'язково потрібно визначити та встановити форми, методи та засоби, які дозволяють цілеспрямовано досягти поставленої цілі;

- Аналізування отриманих результатів з подальшим внесенням корекції;

- Формування мотивації у студентів для входження в процес самоорганізації;

- Розвиток у студентів емоційно-вольових якостей, які необхідно для включення процесу самоорганізації;

- Комунікативні якості, які дозволяють студентові сприймати інформацію, через спілкування;

- (Само)управління, яке включає регулювання процесом самоорганізації, корекція. 
Мета статті - навчити студента правильно розподіляти вільний час в період навчальної діяльності. Розвинути рефлексійні дії при вирішенні ситуаційних задач. Вільно володіти хімічною термінологією. Висказувати свої думки не боячись за свої недоліки в хімічній термінології.

Ми провели анкетування 72 студентів II курсу фармацевтичного факультету з метою виявлення рефлексивності за опросником рефлексивності В.Н. Карандашева. Результати показали, що 28 студента мають низьку рефлективність, що відповідає 38,9\% серед опитуваних, 25 студентів - мають середню рефлективність, що відповідає 34,7\% та 19 студентів - високу рефлективність, це становить 26,4\% серед студентів які були опитані. Середній показник рефлективності опитаних студентів складає 51.8.

Тому головною задачею у формуванні самоорганізації вмінь студентів повинно стати розвиток рефлексії у студентів. Необхідно студента навчити ставати у рефлексивну позицію, тобто розуміти власну дію. В праці Богіна В.Г. [2] для навчально - пізнавальної діяльності головне, щоб відбувалися рефлексивні переноси 3 одної площини в іншу. Для того, щоб навчити студента самоосвіті та самоорганізації потрібно навчити його рефлексії.

Критеріями розвитку рефлексивної здатності студентів можуть бути наступні:

- Зрозумілість для себе наукового інформаційного матеріалу;

- Володіння методами та засобами навчального матеріалу;

- Володіння прийомами обробки змісту, тобто побудова логічного ланцюжка або розуміння ключових понять та хімічної термінології, вміння передавати своїми словами науковий матеріал;

- Володіння прийомами систематизації, тобто робити анотації, схеми, таблиці;

- Вміння складати систему перевірочних завданій для визначення рівня засвоєння.

Рефлексія є основою навчальної самостійної діяльності студента. Також рефлексія навчальної самостійної діяльності є спонукальним моментом. До основних типів рефлексії належать: особистісна, інтелектуальна, комунікативна та кооперативна рефлексія [3].

Самостійна діяльність студента завжди викликає взаємодію між суб‘єктами даного процесу, а саме між викладачем та студентом коли саме мова ведеться про формування етапів самостійної діяльності. У процесі рефлексивного навчання залучені і студент і викладач. Якщо хтось не буде приймати участь в рефлексивному навчанні тоді навчити його не можливо. Творча рефлексія допомагає студентові визначити себе як індивіда, дозволяє усвідомити себе як організатора власного розвитку. Вона надає можливість подолати труднощі, які виникають під час навчання за допомогою переосмислення власного досвіду.

Викладач під час рефлексивного навчання на практичних заняттях готуючись зарання передбачає всі можливі моменти [4]. Викладач лише повинен надихати студента навчити розвивати розумову діяльність, вимушує розвиток вміння проводити аналіз, синтез, порівняння, робити працю та класифікувати за різними ознаками явища, самостійно розбиратися з труднощами знаходячи відповіді в «старих» знаннях, щоб породити нові знання, більш досконалі. Всі ці процеси не відбуваються стихійно, всі навички студент отримує поступово.

Як правила, зажди в процесі навчання виникає взаємодія між студентом та викладачем, також виникає взаємодія між студентом та студентом, тобто самого студента - коли він є учнем, та коли він $є$ викладачем до самого себе в процесі самонавчання. Процес самостійної діяльності грунтується на двох аспектах:

- Комунікативному. В цей момент відбувається насадження взаєморозуміння між суб`єктами навчального процесу. Використовується комунікативна (міжособистісна рефлексія);

- Практична взаємодія. В цьому аспекті студент самостійно позначає зміст навчання. Ця взаємодія $\epsilon$ більш ефективною для студента, коли одночасно будуть залученні: осмислення, усвідомлення, тобто коли спрацьовує інтелектуальна рефлексія.

Таким чином, ми бачимо, що інтелектуальна та комунікативна рефлексія є необхідною умовою для навчальної діяльності студента та навчальної самостійної діяльності студента. Під час інтелектуальної рефлексії відбувається осмислення осмисленого в процесі навчання завдань та одночасно відбувається організація дій, які перетворюють ці елементи.

Під час розвитку самостійної діяльності студента спрацьовує і особистісна рефлексія. Особистісна рефлексія спрямована на самоорганізацію через осмислення навчаючого, через власну усвідомлену діяльність для здійснення самостійної діяльності в навчальному процесі. Цей вид рефлексії спрацьовує через дві форми: мотивація та самооцінка. Самооцінка дає можливість оцінити сили студента, для виконання дії перед початком навчання, а мотивація є спонукальним фактором або силою до дії по вирішенню проблеми або задачі, яка стоїть перед студентом.

Кооперативна рефлексія починає спрацьовувати, як ми спостерігаємо з праці Щедровицького Г.П. [5], коли студент не може вирішити завдання, або завдання студент виконав, але не вірно. Коли у студента виникає така проблема, він починає згадувати та порівнювати свої дії з певним «еталоном» із власного досвіду. Якщо у власному багажу нема певного рішення для розв'язання проблеми, тоді студент починає конструювати інший шлях для вирішення проблеми. Таким чином і виникає кооперація нового способу діяльності, який буде використаний для виконання навчального завдання.

Тобто кооперативна рефлексія спрацьовує на етапі проектування свого рішення, а також при використані етапу самоконтролю та самокорекції в процесі розв‘язку задачі. 
Для того, щоб компоненти рефлексії почали працювати необхідно створити певні умови та особливі ситуації. Яскравою умовою, згідно автора Федорової М.А. [3] є «ситуації розриву». «Ситуація розриву» це деякий бар“єр, перешкода на шляху здійснення діяльності. Тобто, це є фактор, який спонукає працювати рефлексію. Саме бар`єр дає імпульс до руху рефлексії. «Ситуаційний бар`єр» з одного боку спонукає до навчальної самостійної діяльності, а з іншого надає можливість до виникнення рефлексії, яка є основою навчальної самостійної діяльності студента.

Під час навчального процесу студент робить рефлексивні дії:

- Зупинку;

- Відсторонення;

- Фіксацію;

- Об'єктивізацію [6].

Якщо розглядати процес рефлексії під час виконання самостійного розв“язку студентом, то ми бачимо як починають працювати чотири основні дії. Перша зупинка, отримав завдання до самостійної роботи, студент зупиняється для того, щоб ознайомиться з отриманим завданням. Студент проводить першопочаткове ознайомлення з текстом та починає його аналізувати.

Далі спрацьовує другий етап - відсторонення. Для виконання завдання студент розбиває завдання на структурні складові, та одночасно, кожну частину осмислює. Цей аналіз поступово переходить до самоаналізу. Під час самоаналізу відбувається порівняння знань, вмінь, які так конче необхідні для виконання завдання із власного досвіду.

Потім студент надає самооцінку, в рамках якої встановлюється «ситуація розриву» і формується протиріччя між наявним рівнем знань, вмінь та їх рівнем для задоволення рішення завдання. Під час даного етапу відбувається відсторонення та встановлюється співвідношення між «дано» та «знайти» в поставленій задачі. Саме це відсторонення надає змогу студентові зайняти бокове місце і побачити проблему 3 іншого боку. В цей момент вирисовуються схеми для вирішення проблеми.

Коли студент має певну схему, починає вирисовувати певні шляхи для вирішення завдання, він переходить до етапу конкретизації вибраних шляхів. Відбувається логічне побудування розв“язків завдання. Студент поступово від «дано - знайти» перетворює в іншу структуру. «Знайти» стає для нього як ціль його діяльності. Тобто студент будуючи логічні ланцюжки між «дано - знайти» будує розв“язок, тим самим фіксуючі увагу на самопроектуванні в процесі рефлексії.

Потім можна спостерігати останню стадію, коли студент починає повністю самостійно виконувати завдання - спостерігаємо - самореалізацію. У студента відбувається екстраполяція розв“язку завдання в модель процесу виконання навчального завдання. Студент в розумі проговорює етапи розв'язку, а потім, чи усно або письмово, викладає логічну побудовану схему розв ‘язку. Тобто саме відбувається об`єктивізація процесу. Таким чином ми, спостерігаємо, що процес рефлексія в навчанні самостійної діяльності на дидактичній мові приймає вид (рис. 1):

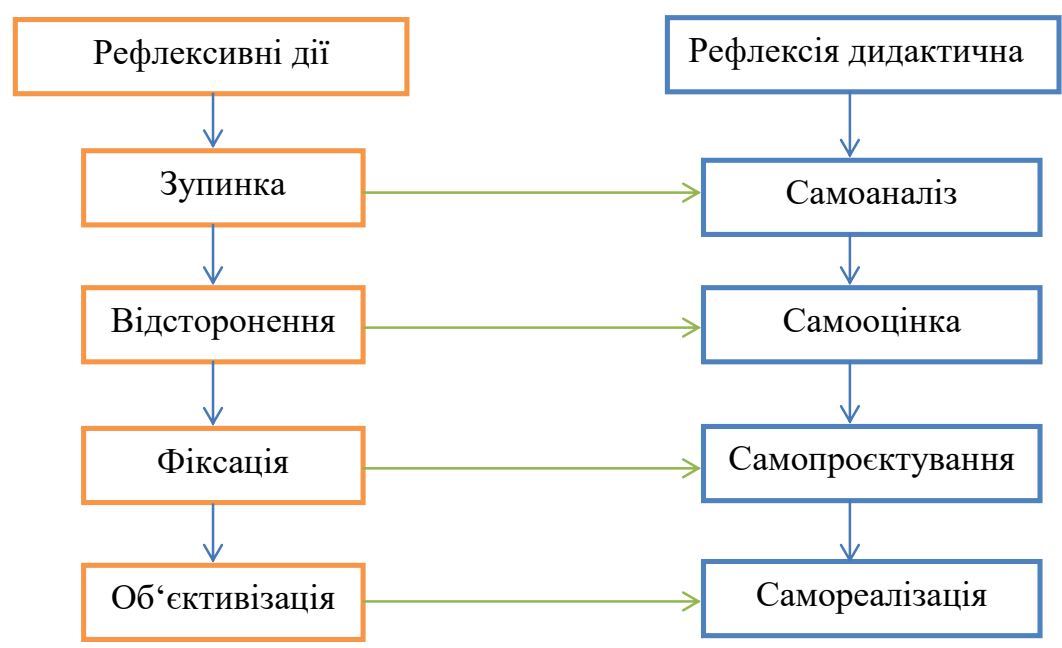

Рис. 1. Схема зв'язку рефлексивних дій з дидактичним трактуванням.

Все це обумовлює логічний розвиток внутрішньої площини розвитку студента в вузі. Всі методи, які викладачі хімічних дисциплін використовують при проведені практичних занять сприяють розвитку рефлексивних дій у студентів.

Також, потрібно не забувати, що для студента провізора необхідно розвинути під час вивчення хімічних наук, певний комплекс компетенцій. В групі хімічних компетенцій можна виділити спочатку два основних блока: 
1. Базові хімічні компетенції, які будуть відноситися до певного кола хімічних дисциплін, які студент тільки починає вивчати у вищому навчальному закладі. До таких дисциплін належать: неорганічна хімія, аналітична хімія, фізична та колоїдна хімія та біоорганічна хімія. Студенти під час вивчення саме таких дисциплін здатні оволодіти базовими хімічними поняттями, хімічною мовою та термінологією; технікою безпеки у хімічних лабораторіях; аналізувати та планувати свої дослідження; вмінням мотивувати відповіді. Саме ці компетенції є фундаментальними для вивчення професійно-орієнтованих дисциплін.

2. Спеціальні хімічні компетенції, які будуть дозволяти отримувати нові знання на самостійному рівні студента, тобто це вміння майбутнього фахівця отримувати знання самостійно під час своєї професійної праці. Ці вміння також надає викладач на перших роках навчання.

Ми можемо виділити ще три основні групи хімічних компетенцій, які розвиваються в медичних вузах під час вивчення хімічних дисциплін.

Комунікативні компетенції. Ці компетенції пов“язані з письмовою та усною формою комунікації. Студенти оволодівають основними поняттями, хімічною термінологією, хімічною мовою. Основними компонентами цієї компетенції є вміння чітко та грамотно формулювати свої думки, пояснювати суть проблеми використовуючи хімічну мову; вміння вести дискусію на професійному рівні, виступати 3 доповідями та приймати участь в наукових хімічних конференціях; вміти правильно і вірно обробляти отримані наукові результати власних досліджень.

- Інформаційно-аналітична компетенція. Це вміння отримувати та переробляти, аналізувати науковий матеріал, включаючи самоаналіз отриманого матеріалу, синтезувати та інтерпретувати хімічні знання. До цієї компетенції входять наступні компоненти хімічних компетенцій, а саме: вміння самостійно знаходити науково-хімічну інформацію не лише в літературних джерелах, а і в ciтi Internet; вміння структурувати науковий матеріал таким чином, щоб його можна було швидко згадати та вчасно проінформувати інших; вміння згадати, зрозуміти, використати хімічні знання та термінологію для аналізу явищ, які відбуваються в навколишньому середовищі; вміння прогнозувати хімічні реакції або явища.

- Інструментально-дослідницькі компетениії. Ці компетенції включають в себе певне правило поведінки під час виконання лабораторних робот, дослідницьких проектів, володіння певними фізико-хімічними методами аналізу, володіння певними навичками проведення наукових дослідів. В свою чергу ця компетенція має групу компонентів, які описують хімічні компетенції, а саме: оволодіння навиками проведення лабораторних робіт за інструкцією; вміння використовувати лабораторне оснащення для проведення наукового досліду; вміння використовувати знання для вирішення хімічних задач; оволодіння фізикохімічними методами аналізу для розв“язку професійних задач; вміння відбирати хімічну інформацію та їі структурувати; вміння логічно представляти наукові результати, правильно подавати та пояснювати власні наукові дослідження.

В кожній групі компетенцій є: когнітивна складова, це набір медико-хімічних знань, які необхідні для формування предметних компетенцій; операційно - діяльністна складова, в яку входить предметні вміння, які визначаються вибором тої чи іншої послідовності інтелектуальних операцій; мотиваційно-особистісна складова, яка описується готовністю студентом до навчання хімічних дисциплінам, усвідомленням цілі власної діяльності; рефлективна складова, яка вводить певні корекції в цілі, в процес наукової діяльності, фіксує результат діяльності. Всі ці компоненти є самостійними частинами та дозволяють сформувати та розвинути хімічні компетенції, але відсутність хоча б одного 3 них будуть формувати дефекти в процесі розвитку хімічних компетенцій.

Як ми спостерігаємо мотиваційно-особистісна складова співвідноситься до цілей та мотивації студентів, до їх прагнень пізнати нове. Також всі результати будуть залежати від рівня готовності студента до вивчення хімічних дисциплін, тобто наскільки студент усвідомлює поставлені цілі перед собою.

Когнетивна складова співвідноситься з діяльністю студента при вивченні наукового матеріалу. Результат також буде залежати від самого викладача, як само буде відбуватися подача наукового матеріалу для студента. Друге співвідношення цієї компетенції з самостійної учбовою діяльністю студента, який саме студент буде мати набір медико-хімічних знань для того, щоб спрацювала компонента самоосвітньої діяльності.

Операційно-діяльнісна складова буде пов'язана з самостійною діяльністю студента та результатами по отриманню знань на практиці. Всі ці моменти включають наявність предметних вмінь та пов'язані з індивідуальною інтелектуальною роботою самого студента.

Рефлексивна складова пов'язана з самоконтролем та самооцінкою студента. Тобто в цій самостійній діяльності вводяться корекції в знання студента, фіксуються певні результати, якими оволодів студени під час вивчення хімічних дисциплін.

Для того, щоб розвинути компетенцій потрібно, щоб студент вмів самоорганізовуватися. Саме у формуванні хімічних компетенцій самоорганізаційна діяльність $є$ педагогічною умовою успішності. Таким чином, щоб найкраще сформувати та розвити хімічні компетенції в процесі самоосвітньої діяльності студента потрібно підтримувати наступні умови на кожному практичному занятті:

- Систематичний процес навчання хімічних дисциплін, в якому потрібно пробуджувати самоосвітню діяльність; 
- Викладачеві, потрібно чітко розробляти інструкції та рекомендації для студентів, які в свою чергу студенти повинні виконувати;

- Викладач, повинен створювати позитивну мотивацію на кожному занятті. Ця мотивація викликає пізнавальну активність у студентів та прагнення самостійно знайти науковий додатковий матеріал, його опрацювати та запам'ятати;

- Збільшення самостійності у студентів, надавати змогу самостійно приймати рішення під час обговорення матеріалу, висказувати свої думки не боячись за свої недоліки в хімічній термінології.

\section{Використана література:}

1. Курнев М.М. Педагогическая система формирования умений самоорганизации студентов юридических вузов МВД РФ: На материале физической подготовки: дис...канд пед наук, специальность: 13.00.08. Саратов, 2005. 195 с.

2. Богина В.Г. Обучение рефлекси как способ формирования творческой личности / под. ред. И.Я. Лернера, И.К. Журавлева. Москва. 1993. С. 159-175.

3. Федорова М.А. Рефлексия как основа учебной самостоятельной деятельности студентов. Психолого-педагогический журнал Гаудеамус, 2017. Т.16. № 1. С. 21-26.

4. Філіппова Л.В. Педагогічна рефлексія у вищій школі. Молодий вчений. 2019. № 2 (66). С. 132-136.

5. Щедровицкий Г.П. Коммуникация, деятельность, рефлексия. Исследования речемыслительной деятельности. Алма-Ата, 1974

6. Макарова Л.Н. Развитие стиля педагогической деятельности преподавателя вуза. Педагогика, 2005. № 6. С. $72-80$.

\section{References:}

1. Kurnev M.M. (2005). Pedagogicheskaya sistema formirovaniya umeniy samoorganizatsii studentov yuridicheskikh vuzov MVD RF: Na materiale fizicheskoy podgotovki. [The pedagogical system of the formation of self-organization skills of students of legal universities of the Ministry of Internal Affairs of the Russian Federation: Based on the material of physical preparation]. Saratov, 2005. 195 pp.

2. Bogina V.G. (1993). Obucheniye refleksi kak sposob formirovaniya tvorcheskoy lichnosti. [Reflexing education as a way of creating a creative personality]. Moskva. pp. 159-175.

3. Fedorova M.A. (2017). Refleksiya kak osnova uchebnoy samostoyatel'noy deyatel'nosti studentov. [Reflection as the basis of students' independent educational activities]. T.16. № 1. pp. 21-26.

4. Filippova L.V. (2019). Pedahohichna refleksiya u vyshchiy shkoli.[ Pedagogical reflection in high school] № 2 (66). pp. 132-136.

5. Shchedrovitskiy G.P. (1974). Kommunikatsiya, deyatel'nost', refleksiya.[ Communication, activity, reflection.] Alma-Ata.

6. Makarova L.N. (2005). Razvitiye stilya pedagogicheskoy deyatel'nosti prepodavatelya vuza. [Development of the style of pedagogical activity of a university teacher]. № 6. pp. 72-80.

\section{Filippova L. V. The development of students' self-organization in the study of chemical disciplines}

It is described how the process of self-organization of students can take place with the help of reflection, which is important for the further formation and self-determination of a person in the world. Become more competitive in the labor market and in the world. The main aspects of the distribution of one's own time during the student's educational activity are given in detail. It is the correct distribution of free time that helps the student learn to self-organize. The main components with which it is possible to develop and form skills for self-organization are considered in detail. The main task in the formation of self-organization of students' skills should be the development of reflection in students. It is necessary to teach the students to take a reflexive position, i.e. to understand their own action. In the work of $V$. Bogin [2] for educational-cognitive activity, the main thing is that there are reflexive transfers from one plane to another. In order to teach a student self-education and self-organization, you need to teach him reflection. The main task in the formation of self-organizational skills, which occur only under the influence of reflective actions, is described, and this is the main thing in the study of chemical disciplines to understand their own actions.

The "situation of rupture" which causes reflective actions at students during the independent decision of a problem is considered in detail. This situation makes it possible to consolidate the acquisition of new knowledge, and at the same time recall the skills that the student already has and project new knowledge into another area of knowledge. The group of chemical competences, which is peculiar to students of pharmaceutical faculties, is given. These competencies are fundamental for the study of professionally oriented disciplines for students of pharmaceutical universities.

Criteria of reflexiveness are characterized, which are closely related to the independent work of the student in higher educational institutions. The process of independent activity of the student during the educational process is based on two main aspects.

It is noted that in order to develop competencies it is necessary for a student to be able to organize himself. It is in the formation of chemical competencies that self-organizational activity is a pedagogical condition for success. Thus, in order to best form and develop chemical competencies in the process of self-educational activities of the student, it is necessary to maintain the following conditions in each practical lesson:

Key words: self-organization, self-determination, "situation of rupture", independent activity, chemical competences. 